\title{
GUANO SUBSIDY AND THE INVERTEBRATE COMMUNITY IN BRACKEN CAVE: THE WORLD'S LARGEST COLONY OF BATS
}

\author{
Goniela IsKali* AND YiXin Zhang \\ Texas State University-San Marcos, 220 E. Sessoms Dr., San Marcos, TX 78666
}

\begin{abstract}
Fluxes of resource subsidy across ecosystems can affect consumer-community dynamics in recipient systems. Bracken Cave is an unusual ecosystem because of the magnitude of allochthonous input of guano that is produced by the largest bat population in the world - a colony of more than 20 million Mexican free-tailed bats (Tadarida brasiliensis). Research on the guano-subsidy ecosystems dynamics of Bracken Cave is limited, but imperative to our understanding and conservation of this extraordinary ecosystem. The objectives of this study are to determine the quantity and quality of guano deposition across seasons and its effect on the macroinvertebrate community and to examine the effect of the cave's habitat characteristics, such as distance from entrances and depth within the guano substrate, on the macroinvertebrate abundance and taxon richness at Bracken Cave. Core samples of guano and macroinvertebrates were collected at increasing distances within the cave on a monthly basis. Guano from the core samples was analyzed with respect to $\mathrm{C}, \mathrm{N}$, and $\mathrm{P}$ to determine guano quality variations. In addition, pitfall trap sampling was employed to supplement the macroinvertebrate core sampling. An estimated dry weight total of $50,500 \mathrm{~kg}$ of guano was deposited on the $3078 \mathrm{~m}^{2}$ of floor from August 2009 to August 2010, with the highest rate recorded in September 2009 and the lowest in January-March 2010. Variations in guano deposits with respect to seasonality do not have a significant effect on macroinvertebrate abundance and richness. On the other hand, habitat characteristics significantly affected the macroinvertebrate abundance and richness in the cave. Macroinvertebrate abundance decreased with increasing depth within the guano substrate. Carbon concentrations were significantly higher in the top layers of guano, while nitrogen and phosphorous concentrations were not significantly different with respect to guano depth. Results from pitfall-trap sampling indicated that macroinvertebrate richness was significantly higher near cave entrances. This study indicates that the invertebrate community at Bracken Cave was relatively stable and experienced few seasonal fluctuations, but was shaped by the micro-habitat characteristics of distance from entrances and depth within the guano substrate. The bats and the nutrients that they contribute play a central role as productivity donors to the bottom-up dynamics of one of the most unusual cave ecosystems in the world.
\end{abstract}

\section{INTRODUCTION}

Fluxes of energy, nutrients, and materials across ecosystems can affect consumer-community dynamics in the recipient systems and produce a variety of ecosystem dynamic outcomes (Polis and Strong, 1996). The rate of input depends on many environmental and organismal attributes and can determine the magnitude of subsidy effects on the recipient ecosystems. Generally, allochthonous inputs increase primary productivity; and consequently, prey and predator populations (Polis et al., 1997). However, large quantities of allochthonous input can destabilize trophic interactions by stimulating the growth of higher consumers, diminishing prey populations. Although in some recipient systems, ample allochthonous input can represent a constant energy supply that cannot be overexploited, and thus, stabilizes ecosystem interac- tions (Anderson and Polis, 2004). This is especially true in unproductive systems, such as caves, that receive regular inputs of subsidies (Schneider et al., 2011; Polis et al., 1997).

Due to light limitation, cave ecosystems rely almost entirely upon allochthonous energy fluxes originating from surface ecosystems (Culver, 1985, 1982). Therefore, communities in caves are profoundly impacted by the resource subsidies that they receive. The types of resources that enter caves vary in terms of regularity, duration, and usability (Schneider et al., 2011). The most prevalent resource inputs to caves are decaying leaf and woody debris that has fallen or washed into caves and carcasses of animals that fall into pit entrances or get lost within the cave (Culver, 1982, Poulson, 2005, Schneider et al., 2011).

*Corresponding Author: goniela_iskali@yahoo.com 
Fecal matter deposited by cave inhabitants, such as crickets and bats, also represents an important, nutrient-rich energy resource for oligotrophic cave ecosystems (Poulson, 2005; Ferreira et al., 2007; Fagan et al., 2007). Bat guano consists of the egested waste and nitrogenous materials of animal metabolism, which are rich in inorganic and organic nutrients (Hutchinson, 1950).

Some caves are inhabited by high-density populations of bats and receive large quantities of nutrient-rich guano. In limestone caves of the southern United States and Mexico, considerable quantities of bat guano have been observed (Hutchinson, 1950). The guano acts as the resource base of their food webs and can support relatively large populations of detrivorous species such as invertebrates, fungi, bacteria, and other microorganisms. These types of caves differ from other cave ecosystems in the sense that they are not oligotrophic. However, our knowledge of the effects of the guano-subsidy input on cave-community dynamics is limited. In general, caves are regarded as some of the least explored, but most fragile, ecosystems in the world (Clements et al., 2006; Vermeulen and Whitten, 1999; Dennis and Aldhous, 2004). The purpose of our study is to examine the effects of guano input on the macroinvertebrate-community dynamics of Bracken Cave, which is a very unusual cave ecosystem in terms of the amount of allochthonous input and a valuable conservation resource in terms of housing the largest population of bats in the world.

Along with energy fluxes, cave-habitat characteristics can play an important role in influencing cave-community dynamics. A multitude of factors such as lithology, cave climate, and proximity to cave entrance define cave habitats and can influence the distribution of organisms that occur within them (Souza-Silva et al., 2011; Biswas, 2010; Lavoie et al., 2007; Ferreira et al., 2007). For example, distance from the cave entrances and depth within the guano create varying microhabitat conditions that may translate to variations in the macroinvertebrate abundance and richness. Cave entrances also provide an opportunity for surface organisms to enter the cave, either accidentally or intentionally, and this may also affect macroinvertebrate community assemblages in the cave (Ferreira et al., 2007). Interactions between energy availability and habitat characteristics create unique microhabitats and ecological niches within a cave. Ferreira et al. (2007) found that organisms in a guano-subsidy cave were more dependent upon their microhabitat than the overall cave conditions. Thus, the variability of energy input and habitat conditions and their interactions must be taken into consideration to gain an understanding of the factors that influence cave communities.

This study focused on the ecosystem interactions at Bracken Cave and tested three hypotheses, 1) that seasonal changes in bat-population densities and the quantity of guano input influence cave invertebrate abundance and taxon richness, 2) that cave-invertebrate abundance and richness will significantly vary with habitat characteristics such as distance from the cave entrances and depth within the guano substrate, and 3) that differences in the carbon, nitrogen, and phosphorous nutrient composition in the guano will indicate guano quality variability and its effect on the macroinvertebrate community. Through this study we gain a greater understanding on the role of guano subsidy input and its effect on the community dynamics of Bracken Cave.

\section{Materials AND Methods}

\section{Bracken CAVE}

Bracken Cave is located in a suburban setting near San Antonio, Texas. The cave and the 282 hectares surrounding it are managed by Bat Conservation International. The cave consists of two rooms that comprise an estimated $3078 \mathrm{~m}^{2}$ (Fig. 1). A maternity colony of more than 20 million Mexican free-tailed bats (Tadarida brasiliensis) inhabits Bracken Cave (BCI, 2013a) during March through October. In addition, the cave is occupied by a significantly smaller overwintering population of Mexican free-tailed bats. Due to the prolonged use of the cave by bats, it is estimated that guano fills about half of the cave volume (Fran Hutchins, pers. comm., February 2011).

\section{Mexican Free-Tailed Bats}

Mexican free-tailed bats (Tadarida brasiliensis; BCI, 2013b) occupy a wide variety of habitats and can be found throughout the southern portion of the United States, but the densest concentrations of this species are found in Texas, where they form maternity colonies numbering in the millions. The majority of the maternity colonies are in limestone caves, in abandoned mines, under bridges, or in buildings. It is estimated that 100 million Mexican freetailed bats come to central Texas each year to raise their young (BCI, 2013b, Cleveland et al., 2006). Nursing females require large quantities of insects that are high in fat, which they obtain by consuming egg-laden moths. The 100 million free-tailed bats living in central Texas caves consume approximately 1,000 tons of insects nightly, a large proportion of which are agricultural pests. Therefore, the ecological and economic impacts of these large bat colonies are highly significant (BCI, 2013b).

\section{MacroinVertebrate Abundance And \\ TAXON RICHNESS}

In order to monitor macroinvertebrate population differences with respect to cave entrances, the cave was divided into three regions of relatively equal area at increasing distance from the natural entrance: entrance zone, twilight zone, and dark zone. However, a smaller artificial man-made ceiling entrance exists in the dark zone of the cave (Fig. 1). Each region was approximately $45 \mathrm{~m}$ in length, with an average width of $30 \mathrm{~m}$. 


\section{BRACKEN BAT CAVE}

Comal County, Texas

Bronton ond tope survey 1963

The University of Texos Grotto

Rodrotted 23 April 1983 by

E. Kostning
Profile (holf-scole)

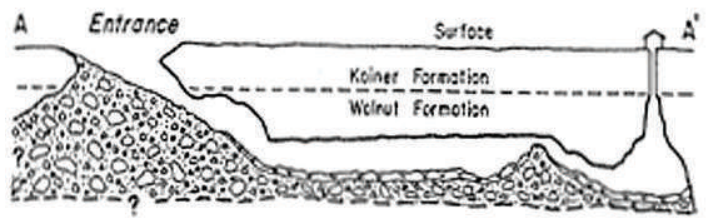

Notes: L. Tolol length is $136 \mathrm{~m}$

2. Cove developed in Wolnut Formotion (Lowet Cretoceous)

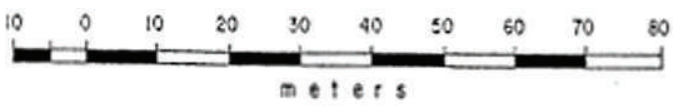

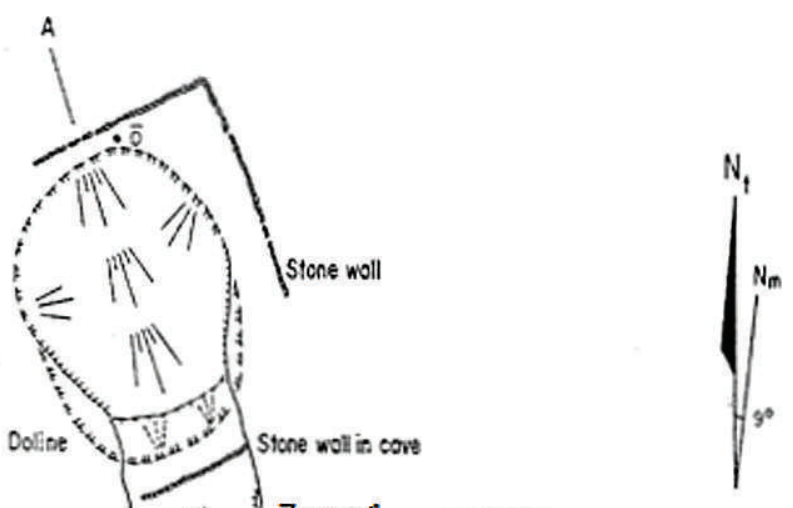

Zone 1

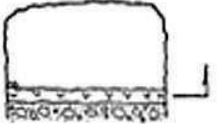

Zone 2

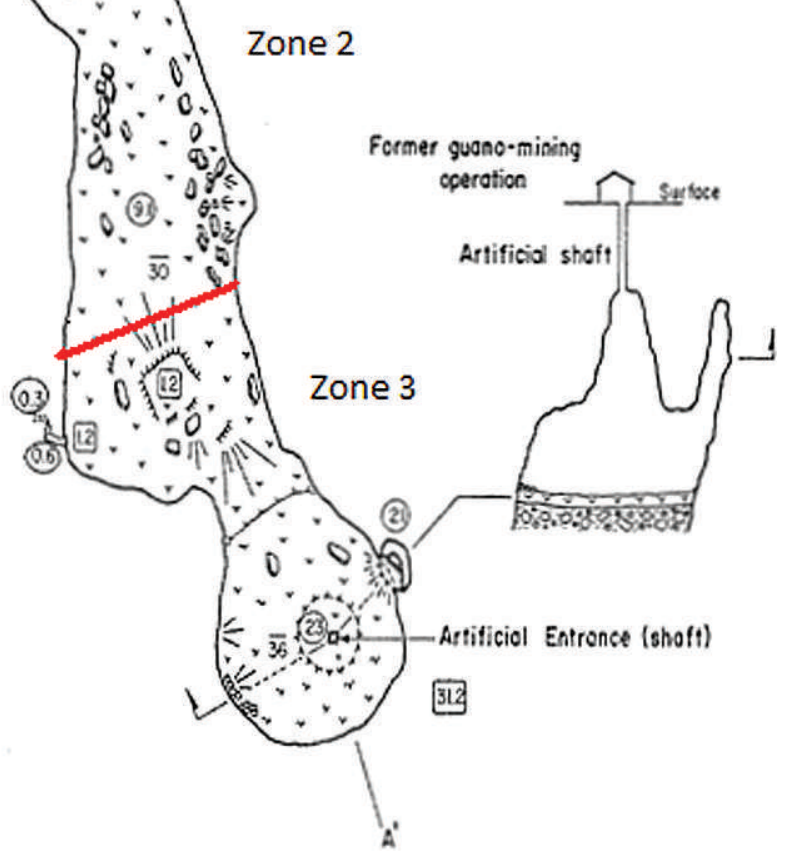

Figure 1. Map of Bracken Cave, Garden Ridge, Texas (modified from Kastning, 1983). The map includes the division of the cave into zones of $\mathbf{4 5} \mathrm{m}$ in length.

We collected three core samples from each region on a monthly basis for five months (August-December 2009). This was accomplished by randomly inserting a PVC pipe sampler $0.08 \mathrm{~m}$ in diameter and $0.91 \mathrm{~m}$ long into the cave floor and determining the taxa richness and abundance of organisms present between the surface and $0.91 \mathrm{~m}$ of guano depth. The method for extracting stratified guano for this study is one that was used by Altenbach and Petit (1972) to study the effects of pollution and heavy metals on the environment. This involved inserting a pipe into the guano, digging a trench around it in order to place a stopper at the bottom, and then extracting the pipe or core sampler. As soon as the sample was collected, three plastic dividers were inserted into the PVC pipe to divide the guano into four $0.23 \mathrm{~m}$ layers and prevent guano and organism displacement during the extraction. The length of the layers and length of the pipe used were determined through preliminary data collection, where $0.91 \mathrm{~m}$ depth of guano was examined using the same pipe-trench method, which showed that guano layers were significantly different in texture and color at approximately every $0.23 \mathrm{~m}$ in depth. These layers roughly correlate to a yearly deposit of guano (Wurster et al., 2007). During this study, we examined the top four apparently distinctive layers of guano and the macroinvertebrates 
within each of these layers. Macroinvertebrates in each core sample layer were separated in the lab from the guano mixture using a $1 \mathrm{~mm}$ sieve, picked and placed in $70 \%$ ethanol for preservation, and later identified to the lowest taxonomic level possible (typically family or genus level).

In addition to core sampling, we also employed pitfall trap sampling to measure macroinvertebrate abundance and richness. The pitfall traps were used to supplement the invertebrate core-sampling method and ensure that our samples contained a more comprehensive representation of the cave organisms. Three pitfall traps $0.06 \mathrm{~m}$ in diameter with a volume of $236.59 \mathrm{~cm}^{3}$ were installed in each zone of the cave for 48 hours in November 2009, April 2010, and July 2010. The pitfall traps were filled with $50 \%$ water and $50 \%$ of a $70 \%$ ethanol solution. Ethanol has been shown to be an effective pitfall trap preservative, and we mixed it with water to reduce evaporation (Aristophanous 2010). Pitfall-trap specimens were preserved in $70 \%$ ethanol and identified to the lowest possible taxonomic level. In addition, pitfall-trap samples were sub-sampled to onefourth for macroinvertebrates larger than $1 \mathrm{~mm}$ and onetwelfth for macroinvertebrates smaller than $1 \mathrm{~mm}$. Subsampling was conducted because of the large number of macroinvertebrates contained in each pitfall trap.

\section{Guano Deposition Rate}

Guano is the base food resource for the food web in Bracken Cave. Therefore, determining the quantity and quality of the guano is essential to understanding this ecosystem. Guano deposition samples were collected in six plastic containers $0.34 \mathrm{~m}$ by $0.21 \mathrm{~m}$ by $0.12 \mathrm{~m}$. Each cave zone (Fig. 1) had two randomly placed containers that were collected every month from September 2009 to August 2010. This was conducted to assess the quantity and seasonal variation of the guano being deposited. The guano was then dried at $60{ }^{\circ} \mathrm{C}$ for 72 hours and weighed to the nearest $0.1 \mathrm{~g}$.

\section{Guano Nutrient Analyses}

Guano collected during core sampling was also examined with respect to nutrient composition. Thirty-six samples $(9$ replicates $\times 2$ seasons $\times 2$ guano depth layers) were analyzed to determine the concentrations of carbon, nitrogen, and phosphorous in guano samples from summer and winter bat-population seasons and top and bottom guano depths. To determine carbon and nitrogen concentrations, samples were processed using the Flash EA 1112 Elemental analyzer. Samples were analyzed for phosphorous content by the Soil Testing Services at the University of Missouri. The samples were dry-ashed using an adaptation of AOAC 985.01 (Isaac, 2009), and phosphorous content was determined through inductively coupled plasma-atomic emission spectroscopy (US EPA 1992).

\section{Statistical Analyses}

An unbalanced ANOVA was used to estimate if there were any significant differences between the guano deposit rates, where weight of the samples was the response variable and the distance from the entrances and seasonality were the two predicting factors. To investigate the variability in macroinvertebrates from the core-sample data with respect to distance from the entrances, guano depth, and seasonality, we employed two linear mixedeffects models. Seasonality was the random predictor variable, and cave zone and guano depth were the fixed predictor variables in the models. The guano depth data were organized to compare the two top layers of guano with the two bottom layers of guano. Macroinvertebrate abundance, as number of macroinvertebrates per sample per month, was the response variable in one of these regression models, and macroinvertebrate richnes, as number of taxa per sample per month, was the response variable in the other model. The abundance data were $\log _{10}$ $(n+1)$ transformed to meet the normality and homoscedasticity assumptions. The pitfall traps were analyzed using unbalanced ANOVAs with macroinvertebrate abundance (number per sample) and richness (taxa per sample) as the response variables and seasonality and cave zone as the predicting factors for both ANOVAs. The macroinvertebrate abundance data from these pit-fall samples was natural-log (ln) transformed to achieve normality and homoscedasticity. Finally, we used two-way balanced ANOVAs to compare the $\mathrm{C}, \mathrm{N}$, and $\mathrm{P}$ content in the samples, and we used one ANOVA for each $\mathrm{C}, \mathrm{N}$, and $\mathrm{P}$ where seasonality and guano depth were used as factors for each of the tests. All analyses were performed using the statistical programming language, $R$.

\section{RESULTS}

\section{Seasonal Guano Deposit Comparisons}

We determined that the amount of guano deposition per month ranged from the highest of $11,337 \pm 637 \mathrm{~kg}$ (September 2009) to the lowest of $66 \pm 50 \mathrm{~kg}$ (JanuaryMarch 2010) when extrapolating to the total cave area (Fig. 2). The average guano deposition in Bracken Cave was approximately $4,210 \pm 989 \mathrm{~kg}$ per month. The deposition of guano varied significantly between months $\left(F_{1,27}=16.87, P<0.001\right)$, (Fig. 2$)$ but did not differ with respect to distance from the entrances when comparing the three cave zones $\left(F_{2,27}=2.68, P=0.09\right)$. Lastly, the total estimated guano deposition in the cave was 50,521 \pm 11,868 kg for August 2009 through August 2010.

\section{Macroinvertebrate Community Structure}

The macroinvertebrate sampling at Bracken Cave collected and identified 754,265 individual macroinvertebrates. Invertebrates were classified in eight orders of at least ten families. Acarina was by far the most abundant order, containing $95.91 \%$ of the macroinvertebrates observed. The second most abundant order was Coleoptera, containing $4.01 \%$ of the macroinvertebrates, and the most

Journal of Cave and Karst Studies, April 2015 •31 
Weight of Guano Deposition $\left(\mathrm{g} / \mathrm{m}^{2}\right)$

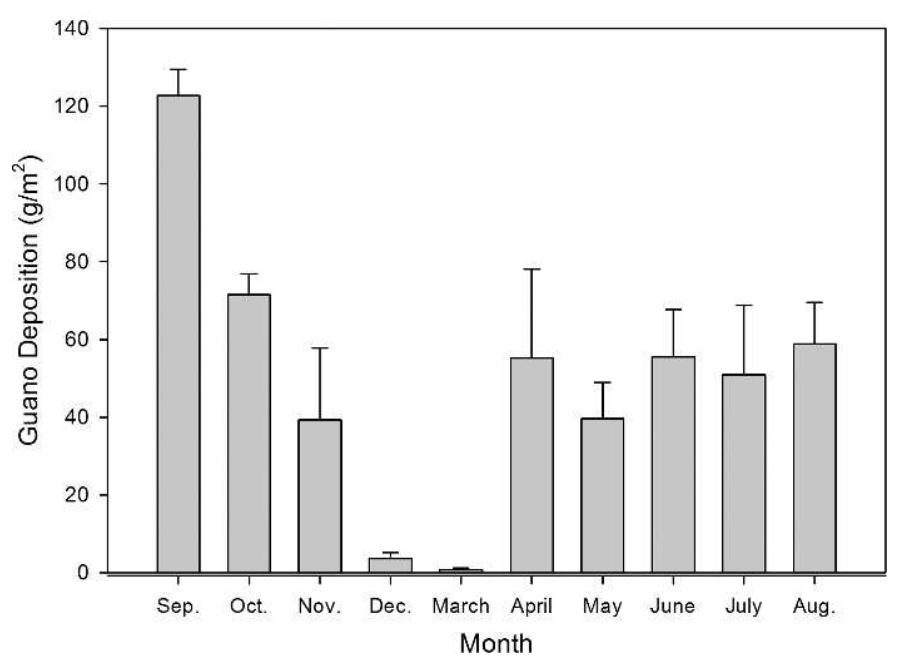

Figure 2. Mean weight in six locations of guano deposition $\left(\mathrm{g} \mathrm{m}^{-2}\right.$ ) per month (September 2009 through August 2010). Error bars are standard error. The guano deposition observed throughout the months varied significantly $\left(F_{1,27}=16.87\right.$, $P<0.001)$.

abundant families of this order were Dermestidae and Tenebrionidae (Table 1).

Linear mixed-effect model analyses revealed that monthly seasonality only explained $28 \%$ of the variation in macroinvertebrate abundance and $2.4 \%$ of the variation in macroinvertebrate taxa richness from the core samples collected August through December 2009. The highest abundance $(14,216.87 \pm 3,633.73$ number per cubic meter per month $\pm \mathrm{SE})$ and richness $(2.22 \pm 0.09$ number of taxa per month) were encountered during the month of September, while the months of August, October, November, and December displayed similar, but lower, values in macroinvertebrate abundance and richness (Fig. 3). In addition, cave zones or distance from entrances did not significantly affect macroinvertebrate abundance $\left(F_{1,115}=\right.$ $1.66, P=0.19)$ and richness $\left(F_{1,117}=0.17, P=0.67\right)$. Zone 2 , or the twilight zone, displayed the highest abundance of $7,351.81 \pm 187.95$ and richness of $1.82 \pm 0.02$, but this was not significantly higher than zone 1 or 3 . Guano depth was significantly correlated with macroinvertebrate abundance $\left(F_{1,117}=8.56, P=0.004^{*}\right)$ but not richness $\left(F_{1,117}=3.46\right.$, $P=0.07$ ) (Fig. 4). The top two layers of guano displayed significantly higher abundance $(5,431.33 \pm 110.84)$ when compared to the bottom two layers of guano $(3,549.40 \pm$ 156.63). Richness of taxa was slightly higher, but not significantly different, in the top layers of guano $(1.80 \pm$ $0.01)$ versus the bottom layers of guano $(1.57 \pm 0.02)$.

The abundance of organisms found during pitfall-trap sampling was not significantly correlated to seasonality $\left(F_{2,13}=3.17, P=0.07\right)$ or cave zones $\left(F_{2,13}=3.16, P=\right.$ $0.07)$. The highest abundance of macroinvertebrates was collected during the month of July $\left(2.39 \times 10^{8} \pm 1.14 \times 10^{8}\right)$ (number of organisms per cubic meter per month), compared to the average seasonality abundance $(1.24 \times$ $\left.10^{8} \pm 0.62 \times 10^{8}\right)$. In addition, the highest abundance of macroinvertebrates was collected in zone $3,2.32 \times 10^{8} \pm$ $1.16 \times 10^{8}$, compared to the average zone abundance of 1.35 $\times 10^{8} \pm 0.71 \times 10^{8}$. However, a significant correlation was found between taxon richness and cave zones $\left(F_{1,13}=8.91\right.$, $P=0.004)$ (Fig. 5), but not seasonality $\left(F_{1,13}=3.48, P=\right.$ 0.06). Zone 2 (4.75 \pm 0.37) (number of taxa/month) displayed significantly lower macroinvertebrate richness

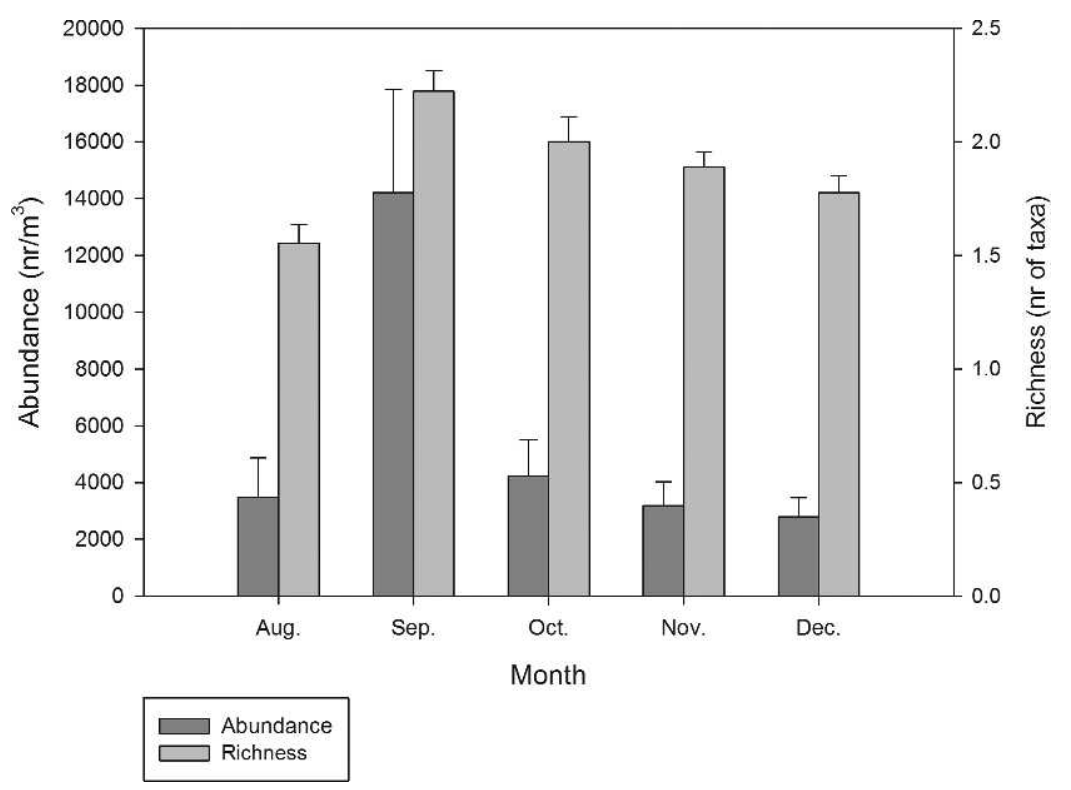

Figure 3. Macroinvertebrate density (number per cubic meter) and richness (number of taxa) $\pm \mathrm{SE}$ of Bracken Cave encountered in core samples from August through December 2009. 


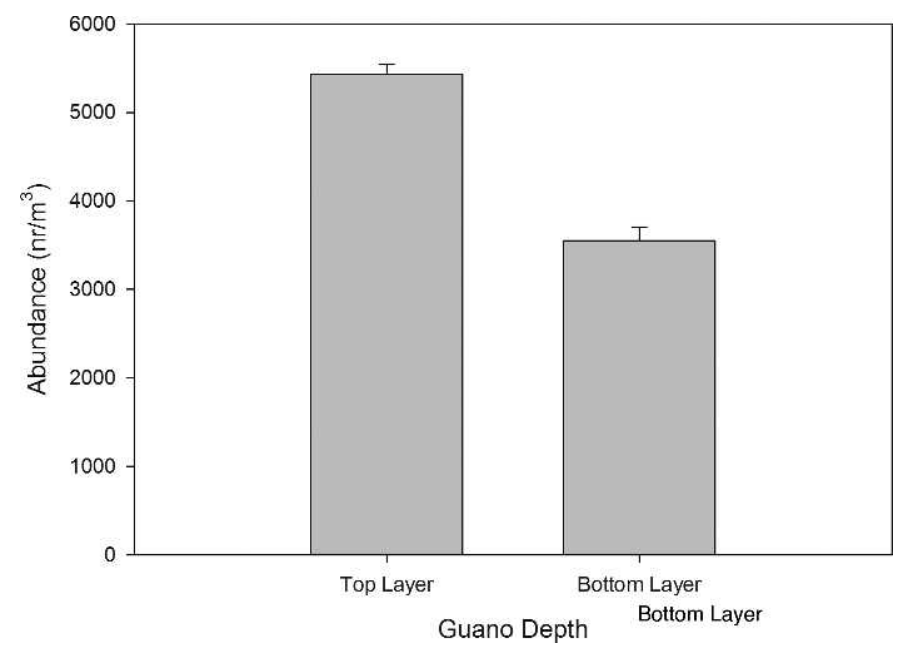

Figure 4. Mean macroinvertebrate density (number per cubic meter) $\pm \mathrm{SE}$ of Bracken Cave with respect to guano depth encountered in the core samples. The top half of the cores $(0$ $0.45 \mathrm{~m})$ displayed significantly higher macroinvertebrate abundance than the bottom half $(0.45-0.91 \mathrm{~m})\left(F_{1,117}\right.$ $=8.56, P=0.004)$.

than zone $1(6.50 \pm 0.56)$ and zone $3(6.63 \pm 0.53)$. The highest macroinvertebrate richness was observed in April 2010 (6.40 \pm 0.98$)$, compared to the seasonal average (5.97 $\pm 0.64)$.

\section{Guano Nutrient Analyses}

Carbon concentrations (moles/g) significantly differed between different layers of guano depth $\left(F_{1,32}=7.04, P=\right.$
$0.01)$, but did not differ with seasonality $\left(F_{1,32}=1.40, P=\right.$ 0.25 ). Moles of carbon per gram were significantly higher in the top layer of guano $\left(0.034 \pm 8.19 \times 10^{-5} \mathrm{~mol} \mathrm{~g}^{-1}\right.$, mean \pm $\mathrm{SE})$ versus the bottom layer $\left(0.031 \pm 3.27 \times 10^{-4}\right)$. The mean overall carbon content found in the samples was $0.033 \pm$ $0.001 \mathrm{~mol} \mathrm{~g}^{-1}$. Alternatively, nitrogen moles per gram did not differ significantly with respect to guano depth $\left(F_{1,32}=\right.$ $0.02, P=0.9)$ or seasonality $\left(F_{1,32}=2.41, P=0.13\right)$. The mean nitrogen content estimated from the samples was $0.009 \pm 0.0002 \mathrm{~mol} \mathrm{~g}^{-1}$. Similarly, phosphorous in moles per gram did not significantly differ with respect to guano depth $\left(F_{1,32}=0.12, P=0.74\right)$ or seasonality $\left(F_{1,32}=1.33, P\right.$ $=0.26$ ) (Fig. 6). The mean phosphorous content estimated from the samples was $0.0005 \pm 2.57 \times 10^{-5} \mathrm{~mol} \mathrm{~g}^{-1}$.

\section{Discussion}

We observed a huge flux of cross-ecosystem subsidy and a high abundance of macroinvertebrates in Bracken Cave, a stable microenvironment of unlimited guano supply. By providing energy and nutrients, the bats play a central role as productivity "donors" to the "bottom-up dynamics" of the cave ecosystem. The guano input at Bracken Cave significantly varied with seasonality due to fluctuations in bat population densities. But these variations do not seem to translate into changes in macroinvertebrate population abundance and richness as indicated by the guano core sampling and pitfall-trap sampling. This is contrary to our first hypothesis and other related studies that have shown cave organisms will respond to fluctuations of nutrient supplies delivered to the cave (Humphreys, 1991; Poulson, 2005). However, Bracken Cave differs from most caves in

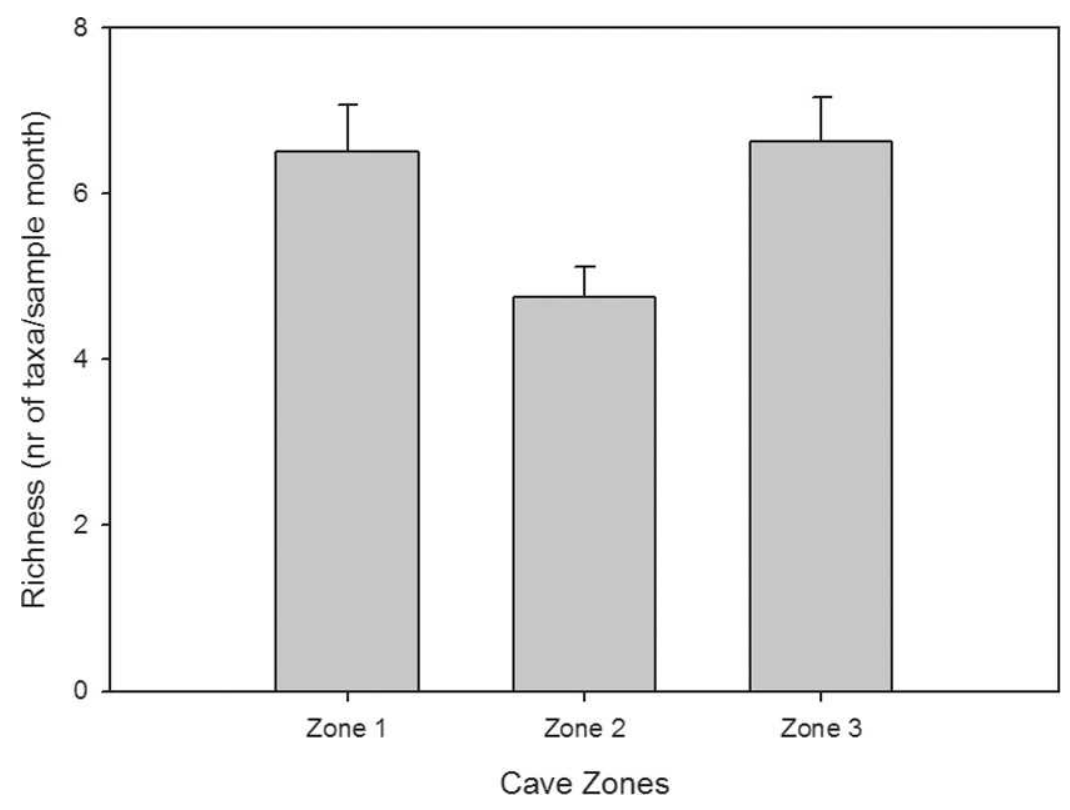

Figure 5. Comparison of mean macroinvertebrate richness $\pm \mathrm{SE}$ (number of taxa) found in the cave zones (Fig. 1) during pitfall-trap sampling. Richness was significantly different between the three cave zones, since zone $\mathbf{2}$ had a significantly lower richness when compared to zones 1 and $3\left(F_{1,13}=8.91, P=0.004\right)$. 


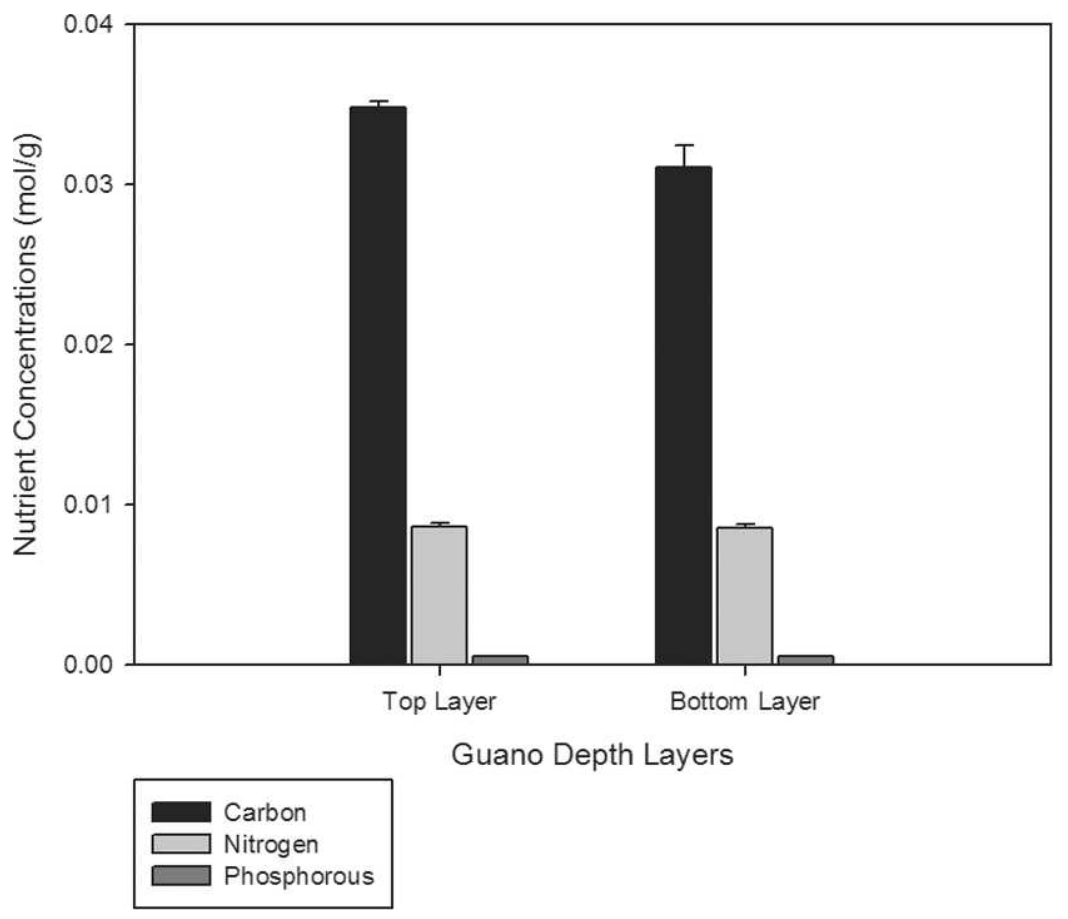

Figure 6. Carbon, nitrogen, and phosphorous concentrations $\left(\mathrm{mol} \mathrm{g}^{-1}\right)$ compared between top $(0-0.46 \mathrm{~m})$ and bottom halves of the $(0.46-0.91 \mathrm{~m})$ guano cores. Carbon content $\left(\mathrm{mol} \mathrm{g}^{-1}\right)$ was the only nutrient that varied significantly with respect to guano depth $\left(F_{1,32}=7.04, P=0.01\right)$.

that there is a constant and plentiful amount of guano available throughout the year, despite the varying densities of bat population and rate of guano deposition. In some places, the guano can reach depths of over 20 meters (Fran Hutchins, pers. comm., February 2011). In addition, nutrient analyses from this study demonstrated that guano contents of carbon, nitrogen, and phosphorous do not differ with respect to seasonality. The constant supply of guano and the lack of seasonal variability in nutrient quality, explains the lack of fluctuations in macroinvertebrate abundance and richness with respect to seasonality.

Secondly, we observed an insignificant difference in macroinvertebrate abundance and taxa richness in the guano core samples at different distances from the entrance. Our results from core samples contradict our second hypothesis and indicate that macroinvertebrate populations are not significantly correlated with the distance from entrances. These findings are supported by our observations that the amount of guano distribution is relatively even throughout the cave and indicate that guano availability, and not distance from the entrance, influenced macroinvertebrate abundance and taxa richness in Bracken Cave. However, we did observe a significant difference in macroinvertebrate richness, but not abundance, from the pitfall trap samples when comparing the three cave zones. The two cave zones with the highest macroinvertebrate richness were near entrances and had a higher incidence of trogloxenes (accidental cave organisms). The negative relationship between cave depth and richness is also supported by other studies (Ferreira and Martins, 1998; Ferreira et al., 2007). Ferreira et al. (2007) also observed a reduction in diversity with increasing distance from the cave entrances in a guano-subsidy cave. It is not surprising that this difference in macroinvertebrate richness was detected from pitfall-trap sampling but not guano-core sampling. Pitfall traps allow for a longer time, and presumably, larger area of sampling, and the probability of capturing rare organisms and actively moving organisms is higher with this method. Additionally, the pitfall trap samples included a higher range of macroinvertebrate sizes, because the guano core samples discriminated against smaller invertebrates (less than $1 \mathrm{~mm}$ ). Thus, cave entrances play an important role in introducing organisms to cave ecosystems and influencing the cave richness of microhabitats near these entrances. However, the distance from the cave entrance does not correlate with guano availability and does not influence the populations of the predominant organisms found at Bracken Cave.

Lastly, analysis of guano core samples indicated that there was a significant difference in macroinvertebrate abundance, but not taxa richness, when comparing the different layers of guano depth. These results were anticipated and concurred with our third hypothesis, because abiotic conditions such as oxygen concentration, moisture, and temperature (Sanders, 1981), and biotic conditions, such as microbial activity, vary with soil or substrate depth (Fierer et al., 2003). Reduced space among guano particles in the deeper layer can be another limiting 
Table 1. Summary of the macroinvertebrates found in Bracken Cave through core sampling and pitfall traps methods (August 2009-July 2009).

\begin{tabular}{llll}
\hline Order & \multicolumn{1}{c}{ Family } & Genus & Species \\
\hline Acarina & & & \\
Araneae & & & \\
Coleoptera & Dermestidae & Dermestes & carnivorus \\
Coleoptera & Histeridae & Carcinops & pumilio \\
Coleoptera & Histeridae & Euspilotus & sp. 1 \\
Coleoptera & Histeridae & Euspilotus sp. 2 \\
Coleoptera & Tenebrionidae & Alphitobius & diaperinus \\
Hemiptera & & & \\
Dermaptera & & & \\
Diptera & & & \\
Pseudoscorpionida & Chernetidae & & \\
Siphonaptera & Ischnopsyllidae & \\
\hline
\end{tabular}

factor. These changes in abiotic and biotic conditions may have led to the variation in the abundance of macroinvertebrates. Another explanation for these results could be the decrease of guano quality with increasing depth and time (Hutchinson, 1950). The nutrient analyses from this study demonstrated that top layers of guano had significantly higher levels of carbon, but not nitrogen and phosphorous, when compared to the bottom layers of guano. We also expected macroinvertebrate richness to follow a similar pattern, but this was not the case. However, macroinvertebrate richness $(>1 \mathrm{~mm}$ invertebrates) at Bracken Cave is relatively low, as the ecosystem is dominated by abundant populations of Dermestidae and Tenebrionidae beetles. These beetles were ubiquitous throughout the $0.91 \mathrm{~m}$ of guano depth analyzed. Perhaps if greater depths of guano are analyzed we may detect differences in macroinvertebrate richness with respect to substrate depth.

We presume that the abundant quantity, equal-area distribution, and equal nutrient composition of guano with respect to season have created a fairly stable ecosystem supported by a considerable amount of cross-ecosystem subsidy in Bracken Cave. This ecosystem experiences relatively few fluctuations in macroinvertebrate abundance and taxa richness with respect to seasonality. Macroinvertebrate richness also does not vary in the guano depth examined, and abundance is not correlated with the distance from the cave entrances. However, evidence from pitfall-trap sampling suggests that cave entrances do play a role in the introduction of accidental macroinvertebrates to the cave ecosystem. The effect of these trogloxenic animals may be insignificant to the overall community dynamics of this ecosystem due to their low incidence.

\section{Conclusion}

This study provides a description of the community and ecosystems dynamics of one of the most unusual, but understudied, ecosystems, Bracken Cave. Our study is the first to focus on the bat-guano subsidy and macroinvertebrate community of this extraordinary cave ecosystem to determine how the habitat characteristics of distance from an entrance and guano depth, guano quantity and quality, and seasonality affect the macroinvertebrate community of Bracken Cave. Our findings indicate that the macroinvertebrate communities of Bracken Cave do not experience large fluxes in abundance or richness with respect to season. But macroinvertebrate populations did fluctuate with respect to distance from the cave entrances and guano depth. Additionally, guano nutrient quality, and not variations in quantity, may also be one factor that influences macroinvertebrate biodiversity in this cave. This study represents an initial but an important and comprehensive view of the Bracken Cave ecosystem. The information gained from this study improves our understanding of the Bracken Cave ecosystem and can aid managers in developing management plans to conserve this distinctive ecosystem.

Concern over cave ecosystems and the cave-limited species that inhabit them has escalated over the last two decades (Schneider et al., 2011). But despite recent advances in cave research, cave ecosystems and the threats that they face remain understudied (Marmonier et al., 1993; Elliott 2000; Hancock et al., 2005). Bracken Cave, located in a suburban setting, is constantly threatened by the effects of urbanization and further development in the growing metropolis of San Antonio (BCI, 2013a). Damages to this extraordinary and not yet fully understood ecosystem would undoubtedly have devastating effects on the bat community, which would, negatively affect the local economy of the region. Cleveland et al. (2006) estimated that pest-control services provided by Mexican free-tailed bats have an average to an annual value of $\$ 741,000$ per year, with a range of $\$ 121,000$ to $\$ 1,725,000$ per year in the south-central Texas area. Therefore, understanding cave ecosystems and their community dynamics is imperative for the preservation of the organisms that occupy them and the benefits gained through the ecosystem services that they provide.

\section{ACKNOWLEDGEMENTS}

We are sincerely grateful to BCI, especially Fran Hutchins and Jim Kennedy, for providing access to the cave, helping us devise and finalize the sampling protocol, aiding in sample collection, and providing necessary information about Bracken Cave and it's bats. We would also like to thank Dr. Benjamin Schwartz and Dr. Weston Nowlin for their helpful suggestions and thesis edits that made this project successful. Lastly, this project would not have been possible without the contribution and endless field and laboratory efforts put forth by the following individuals: Val Yerby, Sam Peterson, Jessica Callery, 
Natasha Lehr, Ryan Stewart, Megan Lindsey, Mario Sullivan, Trey Nobles, etc. Funding for this project was partly provided by the National Speleological Society.

\section{REFERENCES}

Altenbach, J.S., and Petit, M.G., 1972, Stratification of guano deposits of the Free-Tailed Bat, Tadarida brasiliensis: Journal of Mammalogy, v. 53, p. 890-893.

Anderson, W.B., and Polis, G.A., 2004, Allochthonous nutrient and food inputs: Consequences for temporal stability, in Polis, G.A., Power, M.E., and Huxel, G.R., eds., Food Webs at the Landscape Level: Chicago, University of Chicago Press, p. 82-95.

Aristophanous, M., 2010, Does your preservative preserve? A comparison of the efficacy of some pitfall trap solutions in preserving the internal reproductive organs of dung beetles: Zookeys, no. 34, p. 1-16. doi:10.3897/zookeys.34.215.

Bat Conservation International, 2013b, BCI Species Profiles: Tadarida brasiliensis, http://www.batcon.org/index.php/all-about-bats/speciesprofiles.html task $=$ detail \&species $=1738 \&$ country $=43 \&$ state $=$ all $\&$ family=all\&start $=25$ [accessed March 7, 2013].

Bat Conservation International, 2013a, Bracken Cave, http://batcon.org/ index.php/get-involved/visit-a-bat-location/bracken-bat-cave/subcategory. html?layout=subcategory [accessed August 15, 2013].

Biswas, J., 2010, Kotumsar Cave biodiversity: A review of cavernicoles and their troglobitic traits: Biodiversity and Conservation, v. 19, p. 275-289. doi:10.1007/s10531-009-9710-7.

Clements, R., Sodhi, N.S., Schilthuizen, M., and Ng, P.K.L., 2006, Limestone karst of Southeast Asia: Imperiled arks of biodiversity: BioScience, v. 56, no. 9, p. 733-742. doi:10.1641/0006-3568(2006)56[733:LKOSAI]2. $0 . \mathrm{CO} ; 2$.

Cleveland, C.J., Betke, M., Federico, P., Frank, J.D., Hallam, T.G., Horn, J., Lopez, J.D. Jr., McCracken, G.F., Medellin, R.A., Moreno-Valdez, A., Sansone, C.G., Westbrook, J.K., and Kunz, T.H., 2006, Economic value of the pest control service provided by Brazilian free-tailed bats in south-central Texas: Frontiers in Ecology and the Environment, v. 4 p. 238-243. doi:10.1890/1540-9295(2006)004[0238:EVOTPC]2.0.CO;2.

Culver, D.C., 1982, Cave Life: Evolution and Ecology: Cambridge, Massachusetts, Harvard University Press, 189 p.

Culver, D.C., 1985, Trophic relationships in aquatic cave environments: Stygologia, v. 1, p. 43-53.

Dennis, C., and Aldhous, P., 2004, Biodiversity: A tragedy with many players, Nature, v. 430, p. 396-398. doi:10.1038/430396a.

Elliott, W.R., 2000, Conservation of the North American cave and karst biota, in Wilkins, H., Culver, D.C., and Humphreys, W.F., eds., Subterranean Ecosystems: Amsterdam, Elsevier, Ecosystems of the World 30, p. 665-689.

Fagan, W.F., Lutscher, F., and Schneider, K., 2007, Population and community consequences of spatial subsidies derived from centralplace foraging: The American Naturalist, v. 170, p. 902-915. doi:10.1086/522836.

Ferreira, R.L., and Martins, R.P., 1998, Diversity and distribution of spiders associated with bat guano piles in Morrinho Cave (Bahia State, Brazil): Diversity and Distributions, v. 4, p. 235-241.

Ferreira, R.L., Prous, X., and Martins, R.P., 2007, Structure of bat guano communities in a dry Brazilian cave: Tropical Zoology, v. 20 p. $55-74$.
Fierer, N., Schimel, J.P., and Holden, P.A., 2003, Variations in microbial community composition through two soil depth profiles: Soil Biology and Biochemistry, v. 35, p. 167-176. doi:10.1016/S00380717(02)00251-1.

Hancock, P.J., Boulton, A.J., and Humphreys, W.F., 2005, Aquifers and hyporheic zones: Towards an ecological understanding of groundwater: Hydrogeology Journal, v. 13, p. 98-111. doi:10.1007/s10040-0040421-6.

Humphreys, W.F., 1991, Experimental re-establishment of pulse-driven populations in a terrestrial troglobite community: Journal of Animal Ecology, v. 60, p. 609-623. doi:10.2307/5301.

Hutchinson, G.E., 1950, Survey of Existing Knowledge of Biochemistry: 3. The Biochemistry of Vertebrate Excretion: New York, Bulletin of the American Museum of Natural History 96, $554 \mathrm{p}$.

Isaac, R.A., 2009, AOAC Method 985.01, Metals and other elements in plants, in Cunniff, P., ed., Official Methods of Analysis of AOAC International, 16th ed.: Arlington, AOAC International.

Kastning, E.H., Jr., 1983, Geomorphology and hydrogeology of the Edwards Plateau kast, central Texas [PhD thesis]: Austin, University of Texas at Austin.

Lavoie, K.H., Helf, K.L., and Poulson, T.L., 2007, The biology and ecology of North American cave crickets: Journal of Cave and Karst Studies, v. 69, no. 1, p. 114-134.

Marmonier, P., Vervier, P., Gibert, J., and Dole-Olivier, M.-J., 1993 , Biodiversity in ground waters: Trends in Ecology and Evolution, v. 8, p. 392-395. doi:10.1016/0169-5347(93)90039-R.

Polis, G.A., Anderson, W.B., and Holt, R.D., 1997, Toward an Integration of landscape and food web ecology: The dynamics of spatially subsidized food webs: Annual Review of Ecology, Evolution, and Systematics, v. 28, p. 289-316. doi:10.1146/annurev.ecolsys. 28.1.289

Polis, G.A., and Strong, D.R., 1996, Food web complexity and community dynamics: The American Naturalist, v. 147, p. 813-846.

Poulson, T.L., 2005, Food sources, in Culver, D.C., and White, W.B., eds., Encyclopedia of Caves: Burlington, Vermont, Elsevier, p. 255-264.

Sanders, J.E., 1981, Principles of Physical Geology: New York, John Wiley and Sons, $636 \mathrm{p}$.

Schneider, K., Christman, M.C., and Fagan, W.F., 2011, The influence of resource subsidies on cave invertebrates: Results from an ecosystemlevel manipulation experiment: Ecology, v. 92, no. 3, p. 765-776. doi:10.1890/10-0157.1.

Souza-Silva, M., Martins, R.P., and Ferreira, R.L., 2011, Cave lithology determining the structure of the invertebrate communities in the Brazilian Atlantic Rain Forest: Biodiversity and Conservation, v. 20, no. 8, p. 1713-1729. doi:10.1007/s10531-011-0057-5.

US EPA, 1992, Method 6010A, inductively coupled plasma-atomic emission spectroscopy, in Test Methods for Evaluation Solid Waste, Physical/Chemical Methods: United States Environmental Protection Agency SW-846, 3rd Edition.

Vermeulen, J., and Whitten, T., 1999, Biodiversity and Cultural Property in the Management of Limestone Resources: Lessons from East Asia: Washington, World Bank, 144 p.

Wurster, C.M., McFarlane, D.A., and Bird, M.I., 2007, Spatial and temporal expression of vegetation and atmospheric variability from stable carbon and nitrogen isotope analysis of bat guano in the southern United States: Geochimica et Cosmochimica Acta, v. 71 no. 13 , p. 3302-3310. doi:10.1016/j.gca.2007.05.002. 